\title{
Screening of Phytochemical Compounds and Toxic Proteinaceous Protease Inhibitor in Some Lesser-known Food Based Plants and Their Effects and Potential Applications in Food
}

\author{
Ali Aberoumand \\ Department of Fisheries,Natural Resources College, Behbahan Technology University, No 22, second Alley of Ab va Bargh, Zolfeghari \\ Street, Behbahan, Khuzestan province, Iran
}

\begin{abstract}
Compounds or substances which act to reduce nutrient intake, digestion, absorption and utilization and may produce other adverse effects are referred to as anti-nutrients or anti-nutritional factors. Plant sources contain in their raw state wide varieties of anti-nutrients which are potentially toxic. This study was conducted to phytochemical investigation on fruits and plants from India and Iran. Eight plant species were used. A qualitative phytochemical analysis was performed for the presence of polyphenols, saponins, alkaloids, phytic acid, trypsin inhibitor and saponins. The results obtained of the investigated plants showed that the all eight samples were found to be polyphenols but Solanum indicum contains highest value $(7.02 \mathrm{mg} / \mathrm{g})$. All samples showed the presence of alkaloids, and showed presence of saponins except Alocacia and Asparagus and showed presence of steroids except Chlorophytum and Asparagus. Portulaca with(16.9 TIU/g) and Asparagus with $(0.8 \mathrm{TIU} / \mathrm{g})$ contain highest and lowest values of trypsin inhibitor respectively. The phytochemical screening revealed moderate phytate contents except solanum and portulaca. The plants are rich sources of polyphenols appear to have protective effects for human health. Trypsin inhibitor and phytic acid may play a role as an antioxidant in plants and may be beneficial to health when it is consumed.
\end{abstract}

Keywords Phytochemical Screening, Saponins, Steroids, Alkaloids, Anti-nutrients

\section{Introduction}

Fruits and leafy vegetables are believed to occupy a modest place as a source of trace elements due to their high water content. In addition to meeting nutrient intake levels, greater consumption of fruits and vegetables is associated with reduced risk of cardiovascular disease, stroke, and cancers of the mouth, pharynx, esophagus, lungs, stomach, and colon.[1,2]. All edible plants in this study, occurs in the southern part of Iran and India. It is seems this plant contains high contents of anti-nutrients and phytochemicals. Antinutrients or anti-nutritional factors may be defined as those substances generated in natural feedstuffs by the normal metabolism of species and by different mechanisms (for example inactivation of some nutrients, diminution of the digestive process or metabolic utilization of feed) which exerts effect contrary to optimum nutrition. Being an anti-nutritional factor is not an intrinsic characteristic of a

* Corresponding author:

aaberoomand@yahoo.com (Ali Aberoumand)

Published online at http://journal.sapub.org/food

Copyright (C) 2012 Scientific \& Academic Publishing. All Rights Reserved compound but depends upon the digestive process of the ingesting animal. Trypsin inhibitors, which are anti -nutritional factors for monogastric animals, do not exert adverse effects in ruminants because they are degraded in the rumen[1]. Many plant components have potential to precipitate adverse effects on the productivity of farm livestock. These compounds are present in the foliage and seeds of virtually every plant that is used in practical feeding[2].

Plants are an essential component of the universe. Human beings have used plants as medicine from the very beginning of time. After various observations and experimentations medicinal plants were identified as a source of important medicine, therefore, treatment through these medicinal plants, began in the early stages of human civilization. In Islam diseases are cured in two ways, first the cure of soul through prayers and second the cure of ailments through medicines. Several phytochemical surveys have been published, including the random sampling approach which involved some plant accessions collected from all parts of the world. The major chemical substances of interest in these surveys have been the polyphenols and tannins, however, other diverse groups of naturally occurring phytochemicals such as alkaloids and saponins have also been reported. The 
natural active compounds classes or secondary metabolites as alkaloids, saponins, tannins and others have attracted researchers to investigate their chemical, toxicological and pharmacological features. The alkaloids represent a group of natural products that has had a major impact throughout history on the economic, medical, political and social affairs of humans. They are a diverse group of low molecular weight nitrogen-containing compounds derived mostly from amino acids. These secondary metabolites are found in about $20 \%$ of plant species and they classified as true alkaloids, A wide range of biological activities of alkaloids have been reported: emetic, anti-cholinergic, antitumor, diuretic, sympathomimetic, antiviral, antihypertensive, hypnoanalgesic, antidepressant, miorelaxant, antitussigen, antimicrobial and anti-inflammatory. However, the alkaloids and other natural compounds have complex activities and it is necessary to analyze pharmacological activities in the general tissues, linking the structure with the activity presented. It is common to find pharmacological results where a single experimental model generalizes a biological answer, but these can't be accepted because all the pathologies in question are also complex and it is necessary to investigate specific experimental models[3,4,5,6,7,8,9,10,11,12]. This study sets out to investigate of some phytochemical screening of eight Food Plants.

\section{Materials and Methods}

\subsection{Collection of Plant Samples}

Five wild edible plants were also collected from India viz Asparagus officinalis, Chlorophytum comosum, Codia myxa, Portulaca oleracia and Solanum indicum were collected from Iran in October 2006 and April 2007. Remain plants viz Eulophia Ochreata, Momordica dioicia and Alocacia indica were purchased from were collected from various localities of Maharashtra(India)(Table1). Efforts made to collect these plants in flowering and fruiting conditions for the correct botanical identification. Healthy and disease free edible plant part/s selected each variety of fruit and vegetables were collected for phytochemical screening.

\subsection{Samples preparation}

Fresh plants were cleaned with water and external moisture wiped out with a dry cloth. The edible portion of the individual fruits was separated, dried in a hot air oven at $50^{\circ} \mathrm{C}$ for $1 \mathrm{hr}$. The dried samples were then powdered in blander for further study. Some of the plants dried under shade so as to prevent the decomposition of chemical compounds present in them. The Plant foods analysis was carried out in lab of Food Chemistry, Isfahan Technology University, Iran.

\subsection{Determination of the Phytochemical Composition}

The other portion was oven-dried, to a constant weight and ground into powders, which was then packed into dark polythene bags and stored in a desiccator for subsequent uses in the phytocmemical analysis. The phytochemical screening of the samples such as alkaloids, steroids and saponins were carried out as described by Sofowora and Harbone[15].

\subsection{Determination of Trypsin Inhibitor}

According to AOCS 2005, used solutions contain sodium hydroxide, trypsin, acetic acid and BAPA, by method colorimetric in absorption at $410 \mathrm{~nm}$.

\subsection{Determination of Phytic Acid}

Phytate was determined by the methods of Early and DeTurk (1944) by method colorimetric in absorption at 420 $\mathrm{nm}$. used solution contain a solution containing $1.2 \% \mathrm{HCL}$ and $10 \% \mathrm{Na}_{2} \mathrm{SO}_{4}, 0.6 \% \mathrm{HCL}$ containing $5 \% \mathrm{Na}_{2} \mathrm{SO}_{4}, 3 \mathrm{~mL}$ of sulfuric and $3 \mathrm{~mL}$ of nitric acid.

Table 1. Species, habitat and consumption of plants in Iran and India

\begin{tabular}{ccccc}
\hline Botanical name & Family & part(s) used & Habitat & Typical consumption \\
Alocacia indica Sch. & Araceae & Stem & Roadside weed & During famine \\
Asparagus officinalis DC & Liliaceae & Stem & Garden & Regularly \\
Chlorophytum comosum Linn. & Liliaceae & Root Tubers & Garden & During famine \\
Cordia myxa Roxb. & Boraginaceae & Fruits & Disturbed & Regularly \\
Eulophia ocherata Lindl. & Orchidaceae & Tubers & Disturbed & Regularly \\
Momordica dioica Roxb. & Cucurbitaceae & Fruits & Disturbed & Regularly \\
Portulaca oleracia Linn. & Portulacaceae & Stem and leaves & Garden & Regularly \\
Solanum indicum Linn. & Solanaceae & Fruits & Disturbed & Regularly \\
\hline
\end{tabular}




\subsection{Chemical Analysis Total Phenolic Compounds}

The total phenolic contents were determined using Folin-Ciocalteu method according to the literature[23]. Briefly, diluted sample $(0.50 \mathrm{~mL})$ was added to $1: 10$ diluted Folin-Ciocalteu reagent $(2.5 \mathrm{~mL})$. After $4 \mathrm{~min}$, saturated sodium carbonate solution (about $75 \mathrm{~g} / \mathrm{L}, 2 \mathrm{~mL}$ ) was added. After $2 \mathrm{~h}$ of incubation at room temperature, the absorbance of the reaction mixture was measured at $760 \mathrm{~nm}$. Gallic acid was used as a reference standard, and the results were expressed as milligram gallic acid equivalent (mg GAE)/g dry weight of plant material.

\section{Results and Discussion}

The phytochemical screening revealed that Chlorophytum comosum root tubers is very rich in steroids, and phytates (Table 2). All these have potential health promoting effects, at least under some circumstances (Dillard, and German, 2000). Also same Table shows some of the anti-nutrients present in Chlorophytum comosum root tubers. We found low polyphenols content in this plant. It is lower than those reported by Apori et al,[3]. Chlorophytum comosum has moderate phytate content. It is lower than those reported by (Elegbede, 1998). Phytic acid binds calcium, iron, zinc and other minerals, thereby reducing their availability in the body $\mathrm{FAO}[12]$, It also inhibits protein digestion by forming complexes with them. However, the phytate content can further be lowered by processing[13]. The knowledge of the phytate level in foods is necessary because high concentration can cause adverse effects on the digestibility. Phytate forms stable complexes with $\mathrm{Cu}^{2}+, \mathrm{Zn}^{2}+, \mathrm{Co}^{2}+, \mathrm{Mn}^{2}+, \mathrm{Fe}^{2}+$ and $\mathrm{Ca}^{2}+$. Saponins reduce the uptake of certain nutrients including glucose and cholesterol at the gut through intra-lumenal physicochemical interaction. Hence, it has been reported to have hypocholesterolemic effects[14], and thus they may aid in lessening the metabolic burden that would have been placed on the liver. Phytic acid has been considered as an anti-nutritional component in cereals, seeds and beans. Research has traditionally focused on its structure that gives it the ability to bind minerals, proteins and starch, and the resulting lower absorption of these elements. However, resent research have shown that phytic acid has many health benefits. Phytic acid has antioxidant, anticancer, hypocholesterolemic and hypolipidemic effects. In fruits and vegetables, phytic acid helps to prevent oxidative browning by inhibiting polyphenol oxidase. Phytic acid may be used as a safe preservative and antioxidant in food products. Phytic acid is an antioxidant and chelating agent. It suppresses oxidative reactions catalyzed by iron[15].

Protease inhibitors are widely distributed within the plant kingdom, including the seeds of most cultivated legumes. Protease inhibitors have the ability to inhibit the activity of proteolytic enzymes within the gastrointestinal tract of animals[13]. Trypsin inhibitor and chymotrypsin inhibitor are protease inhibitors occurring in raw legume seeds. Protease inhibitors are the most commonly encountered class of anti-nutritional factors of plant origin. These inhibitor shave been reported to be partly responsible for the growth-retarding property of raw legumes. The retardation has been attributed to inhibition of protein digestion but there is evidence that pancreatic hyper-activity, resulting in increased production of trypsin and chymotrypsin with consequent loss of cystine and methionine is also involved[16]. Trypsin inhibitors have been implicated in reducing protein digestibility and in pancreatic hypertrophy[17]. Trypsin inhibitors are polypeptides that form well characterized stable complexes with trypsin on a one-to-one molar ratio, obstructing the enzymatic action. Protease inhibitors are inactivated by heat especially moist heat, because of even distribution of heat[18].

Table 2. Phytochemical constituents of plants species

\begin{tabular}{|c|c|c|c|c|c|c|c|c|}
\hline Species & $\begin{array}{c}\text { Per- } \\
\text { sian/Indi } \\
\text { an names } \\
\end{array}$ & $\begin{array}{l}\text { English } \\
\text { name }\end{array}$ & $\begin{array}{l}{ }^{a} \mathrm{Phe} . \\
\mathrm{mg} / \mathrm{g}\end{array}$ & ${ }^{\mathrm{b}}$ Alk. & ${ }^{\mathrm{c}}$ Sap. & $\begin{array}{l}{ }^{\mathrm{d}} \text { Phy. } \\
\mathrm{mg} / 100 \mathrm{~g}\end{array}$ & $\begin{array}{l}\text { e Try In. } \\
\text { TIU/g }\end{array}$ & ${ }^{\mathrm{f}}$ Ste. \\
\hline Alocacia indica & $\begin{array}{c}\text { Mankan } \\
\mathrm{da}\end{array}$ & Poly Dwarf & 0.87 & - & +3 & 312.4 & 7.9 & - \\
\hline Asparagus officinalis & $\begin{array}{c}\text { Marchub } \\
\text { eh }\end{array}$ & $\begin{array}{l}\text { Asparagus } \\
\text { root }\end{array}$ & 3.17 & - & +4 & 340.8 & 0.8 & +4 \\
\hline Portulaca oleracia & Parpin & Moss Rose & 5.86 & - & - & 823.6 & 16.9 & - \\
\hline Momordica dioica & Kaksa & $\begin{array}{l}\text { Wild Bal- } \\
\text { sam apple }\end{array}$ & 3.69 & - & - & 284.2 & 9.3 & - \\
\hline Eulophia ocherata & $\begin{array}{l}\text { Salab } \\
\text { Panja }\end{array}$ & Wild coco & 2.43 & - & - & 255.6 & 3.1 & - \\
\hline Solanum indicum & Angirak & Egg plant & 7.02 & - & - & 695.8 & 10.6 & - \\
\hline Cordia myxa & Sepastan & $\begin{array}{c}\begin{array}{c}\text { Large } \\
\text { sebesten }\end{array} \\
\end{array}$ & 4.02 & - & - & 248.0 & 1.39 & - \\
\hline Chlorophytum comosum & Sajafi & $\begin{array}{c}\text { Spider } \\
\text { Plant } \\
\end{array}$ & 1.36 & - & - & 468.8 & 4.7 & +4 \\
\hline
\end{tabular}

Values are Means \pm SD of triplicate determinations

${ }^{\mathrm{a}}$ Phe. $=$ Total phenols, ${ }^{\mathrm{b}}$ Alk. $=$ Alkaloids, ${ }^{\mathrm{c}}$ Sap. $=$ Saponins, ${ }^{\mathrm{d}}$ Phy. $=$ Phytic acid, ${ }^{\mathrm{e}}$ Try. $=$ Trypsin inhibitors. ${ }^{\mathrm{f}}$ Ste.$=$ Steroids 
Table 3. Total phenolics of eight edible plants obtained from India and Iran

\begin{tabular}{cccccccccc}
\hline Plants & A. indica & A. officinalis & P. oleracia & M. dioica & E. ocherata & S. indicum & C. myxa & C. comosum \\
Total phenols $(\mathrm{mg} / \mathrm{g})$ & $0.87 \pm 2.1$ & $3.17 \pm 2.1$ & $5.86 \pm 2.1$ & $3.69 \pm 2.1$ & $2.43 \pm 2.1$ & $7.02 \pm 2.1$ & $4.02 \pm 2.1$ & $1.36 \pm 2.1$ \\
\hline
\end{tabular}

Data are displayed from mean values with three repeat \pm SD

Bold values indicate good sources of antioxidant compounds.

The values of bioactive substances present in Portulaca oleracea such as polyphenols were closely related to those earlier reported by Abulude[1] on plants such as mangifera indica, Techtona garandis and Cola nitida. It has been reported that the presence of bioactive substances in plants play a role in preventing colorectal carcinoma, hyperchloestrolcamia and renal calculi[19]. It is documented the absent of saponins is negative point because it control human cardiovascular disease and reduce cholesterol. Poly phenols have been shown to have antibacterial, anti-inflammatory, antiallergic, antiviral and antineoplastic activity[20].

Phenolic compounds could be a major determinant of antioxidant potentials of food plants and could therefore be a natural source of antioxidants and because phenolic compounds have been associated with the health benefits derived from consuming high levels of fruits and vegetables, Therefore, Solanum indicum Linn. has high preservation capacity and nutritional values, because total phenolic compounds prevent from damage of nutrients contain double bonds such fatty acids, flavor compounds even proteins and amino acids and other compounds[21].

The amount of total phenolics varied in different plant foods and ranged from 0.87 to $7.02 \mathrm{mg} \mathrm{GAE} / \mathrm{g}$ of dry material. The highest total phenolic levels were detected in "Solanum indicum" and the lowest in "Alocaccia indica" (Table $3)$. The amount of total phenolic compounds in all tested plant foods was higher than the other Lamiaceous plants reported such as Thymus vulgaris[22], Mentha piperita, Melissa officinalis and Rosmarinus officinalis (Lister and Wilson, 2001). Some selected phenolics of these plant foods, have previously been separated and identified by comparison with authentic standards using reversed-phase high performance liquid chromatography (HPLC), and rosmarinic acid was the predominant phenolic acid in these plant foods[23]. The ranking order of eight plant species from point of view of antioxidant(phenolic compounds) amounts was as follows: $S$. indicum $>$ P.oleracia $>$ C.myxa $>$ M.dioica $>A$. officinalis $>$ E. ocherata $>C$. comocum $>A$. indica. Many factors could contribute to this variation, such as the plant variety, growing condition, maturity, season, geographic location, soil type, storage conditions and amount of sunlight received. Other contributing factor for this difference may be also due to sample preparation and analytical procedures[24]. More than 4000 phenol compounds (flavonoids monophenols and polyphenols) are found in vascular plants. Phenolic compounds, such as querecetin, rutin, narigin, catechine, caffeic acid, gallic acid and chlorogenic acid are very important plant constituents. The type of phenolic compounds is an important factor since following consumption of fruits, phenolics are usually pre- sent in plasma at concentration not exceeding $10 \mu \mathrm{M}$. There are several factors involves in determining the ratio of free to conjugated phenolics in plasma. Among these factors are the type of polyphenol, the fruit stage of maturity, the state of health of the fruit, method of harvesting and storage[25]. Yet, current data in the literature on the relationship between the polyphenol content of plants and their antioxidant activity are sometimes contradictory. While some authors have observed such a high correlation between the two others found no such correlation exists or only a very weak one[26,27].

\section{Conclusions}

In conclusion, our results show that presence of anti- nutrients in plant protein sources for livestock feeding is a major constraint that reduces their full utilization. To be able to justify the overall nutritional potential or value of any plant protein source, proper assessment of the type, nature and concentration of the anti-nutrients present in the protein source and also the bioavailability of nutrients to the ingesting animal is necessary.

The Eulophia ochreata and Cordia myxa plants present the lowest values of total phytic acid and Cordia myxa and Asparagus officinalis have very low concentrations of trypsin inhibitor. Even if all plants have a safe concentration of total phytic acid and trypsin inhibitor, the gap between storage and the processing could imply passage of time and the amount of these compounds could increase. Alocacia indica and Eulophia ochreata and Chlorophytum comosum often have high values of trypsin inhibitor; for these reasons, it is better to employ them in low temperature processes such as minimally processed foods and stir-fry foods, because they have high concentrations of trypsin inhibitor that could increase during the storage period. 2rd Group: Asparagus officinalis, Cordia myxa, Solanum indicum These cultivars should not be used in high temperature processes and should be cooked without the peel. We suggest their use for domestic purposes and home cooking. There are significant differences in proteinase inhibition and antioxidant activity. If these differences are confirmed in the subsequent studies, it should be possible to make application research focused on development of new functional food and nutraceuticals or new secondary metabolites as bioactive compounds. Its addition to foods inhibits lipid peroxidation and concomitant oxidative spoilage, such as discoloration, putrefaction, and syneresis. A multitude of other industrial applications are based on the antioxidant function of phytic acid.

\section{ACKNOWLEDGEMENTS}


Author sincerely thanks Behbahan Technology University, Iran for providing facilities. This research project was financially support by the Behbahan Technology University, Iran.

\section{REFERENCES}

[1] Ali Aberoumand and Deokule S.S. 2010. Elements Evaluation of Some Edible Vegetables and Fruits of Iran and India. Asian Journal of Agricultural Sciences 2(1): 35-37.

[2] Ali Aberoumand and Deokule S.S. 2009. Studies on Nutritional Values of Some Wild Edible Plants from Iran and India, Pakistan Journal of Nutrition 8 (1): 26-31.

[3] Abulude, F.O. 2007. Phytochemical screening and mineral contents of leaves of some Nigerian woody plants. Research Journal of Phytochemistry,; 1 (1): 33 - 39.

[4] Alobo, A.P. 2003 "Proximate Composition and Functional Properties of Pleurotus tuberregium sclerotia Flour and Protein Concentrate". Plant Foods for Human Nutrition,; 58(3):1-9.

[5] Apori, S.O. Long, R.J. Castro, F.B. and Ørskov, E.R. 2000 "Chemical Composition and Nutritive Value of Leaves and Stems of Tropical Weed Chromolaena odorata". Grass Forage Science,;55(1):77-81.

[6] Basu, S.K. Thomas, J.E. and Acharya, S.N, 2007 "Prospects for Growth in Global Nutraceutical and Functional Food Markets: A Canadian Perspective". Austrian Journal Basic Applied Science,;1(4): 637-649.

[7] Bressani, R., and Sosa, J.L. 1990. Effects of processing on the nutritive value of Canavalia Jackbeans[Canavalia ensiformis (L.)]. Plant Foods Human Nutrition,; 40: 207-214.

[8] Chaney, S.G. "Principles of Nutrition I: Macronutrients". In: Textbook of Biochemistry, with Clinical Correlation, 6th ed. Devlin, T.M. (ed.). John Wiley and Sons: New York, NY. 2006. pp.1071-1090.

[9] Dillard, C.J., and German, J.B. 2000 "Phytochemicals: Nutraceuticals and Human Health". Journal of Science Food Agricultural,;80(12):1744-1756.

[10] Elegbede, J.A. "Legumes". In: Nutritional Quality of Plant Foods. Osagie A.U. and Eka, O.U. (eds.). Post Harvest Research Unit, Department of Biochemistry, University of Benin: Benin City, Nigeria. 1998.pp.120-133.

[11] Eriyamremu, G.E., and Adamson, I. 1994 "Early Changes in Energy Metabolism in Rats Exposed to an Acute Level of Deoxycholate and Fed a Nigerian-Like Diet". Annual Nutrition Metabolism,; 38:174-183.

[12] Esenwah, C.N., and Ikenebomeh, M.J. 2008 "Processing Effects on the Nutritional and Anti-Nutritional contents of African Locust Bean (Parkia biglobosa Benth) Seed". Pakistan Journal of Nutrition,; 7(2): 214-217.

[13] FAO. "Roots, Tubers, Plantains, and Bananas in Human
Nutrition". FAO Corporate Document Repository: Rome, Italy. 1990 .

[14] FAO/WHO/UNU. "Energy and Protein Requirements: Report of a Joint FAO/WHO/UNU Expert Consultation”. WHO Technical Report Series. 1991.p.724.

[15] Fasidi, I.A., and Olorunmaiye, K.S. 1994 "Studies on the Requirements for Vegetative Growth of Pleurotus tuber-regium (Fr.) Singer, a Nigerian Mushroom. Food Chemistry,;50: 397-401.

[16] Harbone, J.B. Phytochemical Methods: A Guide to Modern Technique of Plant Analysis, 2nd ed. Chapman and Hall: New York, NY. 1973.

[17] Nwokolo, E.N., and Bragg, B.B.1977. Influence of phytic acid and crude fiber on the availability of minerals from protein supplements in growing chicks. Journal of Animal Science,;57: 475-477.

[18] Marounck, M., Duskova, D, and Brezima, D. 2001. Occurrence, biological activity and implications of phytic acid in nutrition. Biological Listy,; 65: 103-111.

[19] Oguntona, T. "Green Leafy Vegetables". In: Osagie AU and Eka OU (eds). Nutritional Quality of Plant Foods. Post Harvest Research Unit, Department of Biochemistry, University of Benin: Benin City, Nigeria. 1998.pp.120-133.

[20] Ojiako, O.A., and Igwe, C.U. 2008. "The Nutritive, Anti-Nutritive and Hepatotoxic Properties of Trichosanthes anguina (Snake Tomato) Fruits from Nigeria". Pakistan Journal of Nutrition,;7(1): 85-89.

[21] Ka" hko" nen, M.P. Hopia, A. I. Vuorela, H. J. Rauha, J. P. Pihlaja, K. Kujala, T .S. and Heinonen, M. 1999. Antioxidant activity of plant extracts containing phenolic compounds. Journal of Agricultural and Food Chemistry,; 47(10): 3954-3962.

[22] Kaur, C. and Kapoor, H.C. 2002. Antioxidant activity and total phenolic content of some Asian vegetables, Intern. Journal of Food Science and Technology,;37: 153-161.

[23] Lister, E. Wilson, P.Measurement of total phenolics and ABTS assay for antioxidant activity (personal communication). Crop Research Institute, Lincoln, New Zealand. 2001.

[24] Mazumder, A. Neamati, N. Sunder, S. Schulz, J. Pertz, H. Eich, E.and Pommier, V. 1997. Curcumin analogues with altered potencies against hiv-1 integrase as probes for biochemical mechanisms of drug action. Journal of Medicine Chemistry,; 40: 3057-3063.

[25] Pietta, P.G. Flavonoids in medicinal plants. In C. A. RiceEvans, \& L. Packer (Eds.), Flavonoids in health and disease, New York: Dekker. 1998.pp.61-110.

[26] Sellappan, Phenolic compounds and antioxidant capacity of Georgia-grown blueberries and blackberries, Journal of Agricultural and Food Chemistry, 2002;50: 2432-2438.

[27] Spanos, G.A. and Wrolstad, R.E. 1990Influence of processing and storage on the phenolic composition of Thompson seedless grape juice. Journal of Agricultural and Food Chemistry,38: 1565-1571. 